\title{
PENGUASAAN AFIKSASI PADA MAKALAH MAHASISWA MALAYSIA UIN SUNAN AMPEL SURABAYA
}

\author{
Ira Eko Retnosari \\ Dosen PBSI FKIP-Universitas PGRI Adi Buana Surabaya \\ ira_eko_80@yahoo.com
}

\begin{abstract}
Abstrak: Artikel ini bertujuan mendeskripsikan penguasaan afiksasi pada makalah mahasiswa Malaysia UIN Sunan Ampel Surabaya. Pendekatan yang digunakan pada artikel ini adalah deskriptif kualitatif dengan pengumpulan data menggunakan metode dokumentasi. Prosedur pengumpulan data dalam penelitian ini adalah (1) pengumpulan makalah, (2) pemfotokopian makalah, (3) pembacaan makalah, (4) penandaan dengan stabilo, (5) pengklasifikasian, (6) pengodean, (7) pembuatan kartu.Penganalisisan data dalam penelitian ini menggunakan metode deskriptif. Tahaptahap yang digunakan dalam penganalisisan data adalah (1) pengumpulan data, (2) pengklasifikasian data, dan (3) pengeksplanasian. Data artikel ini ialah kata-kata dalam makalah mahasiswa Malaysia UIN Sunan Ampel Surabaya dan sumber data artikel ini adalah makalah mahasiswa Malaysia UIN Sunan Ampel Surabaya. Hasil analisis artikel ini ditemukan proses afiksasi dan pemaknaanya meliputi (a) prefiks, yaitu pe(N)- ,ber-, se-, me(N)-, ter-dan di-. (b) sufiks, yaitu -an, -kan, -nya, dan -i. (c) konfiks, yaitu me(N)-kan, ke-an, me(N)-i, ber-kan, di-kan, di-i, pe(N)-an, di-kan, dinya, dan se-nya.
\end{abstract}

Kata kunci: proses morfologis, afiksasi, makalah mahasiswa Malaysia

\begin{abstract}
This article aims to describe the mastery of affixation on student papers Malaysia UIN Sunan Ampel Surabaya. The approach used in this article is descriptive qualitative. The data collection method is used documentation. Data collection procedures in this article are (1) the collection of papers, (2) copying papers, (3) readings papers, (4) marking with highlighter, (5) classification, (6) coding, (7) the manufacture of the card. Analysis of the data in this study used a qualitative descriptive method. In this method, use the following steps: (1) the selection of data, (2) classification of data, and (3) an explanation. In this article, the data in words in a Malaysian student papers UIN Sunan Ampel Surabaya. Meanwhile, the source of the data acquired from Malaysian student papers UIN Sunan Ampel Surabaya. This article analyzes the results found affixation process and the meaning of affixation include (a) prefix: pe(N)-, ber-, se-, me(N)-, ter-, and di-. (b) suffix: an, -kan, -nya, and -i, (c) konfiks: me(N)-kan, ke-an, me(N)-i, ber-kan, di-kan, di-i, pe(N)-an, di-kan, di-nya, and se-nya.
\end{abstract}

Keywords: morphological processes, affixation, student papers Malaysia 


\section{PENDAHULUAN}

Arus komunikasi dan transportasi yang sangat dahsyat mengakibatkan seseorang dapat melintasi dunia dengan mudah pada era globalisasi ini. Hal tersebut tidak hanya terjadi pada sektor pariwisata, tetapi juga merambah ke berbagai sektor, seperti pendidikan.

Para pelajar asing yang melanjutkan studi ke luar negeri secara tidak langsung dituntut untuk menguasai bahasa asing tersebut. Mereka yang berstatus mahasiswa sangat erat dengan kegiatan menulis. Dalam perkuliahan, mahasiswa diwajibkan menulis karya tulis ilmiah (KTI). Penulisan KTI memunyai kaidahkaidah tertentu. Hal itu dapat menyebabkan hambatan bagi mahasiswa asing. Di Indonesia, ketidakmampuan menggunakan bahasa Indonesia dengan benar tampaknya merata pada semua golongan, yaitu siswa, mahasiswa, dan jurnalis (Chaer, 2013:29).

Adapun kesalahannya meliputi kesalahan pilihan kata, kesalahan susunan kalimat, dan kesalahan isi kalimat. Menurut Chaer (2013:32), penyebab warga Indonesia tidak mampu secara maksimal berbahasa dengan baik dan benar adalah bahasa Indonesia bukan bahasa ibu dan sikap negatif terhadap bahasa Indonesia.

Sikap negatif terhadap bahasa Indonesia terdapat pada semua warga Indonesia, termasuk mahasiswa. Mahasiswa sulit memahami kaidahkaidah penulisan skripsi. Hal tersebut terlihat dengan banyaknya pendampingan dan pembinaan bahasa, khususnya kegiatan menulis. Kenyataan inilah yang menjadi alasan bahwa perlunya perhatian khusus terhadap kompetensi menulis mahasiswa asing.

Proses morfologis adalah suatu proses pembentukan kata dari sebuah bentuk dasar dengan pembubuhan afiks (dalam proses afiksasi), pengulangan (dalam proses reduplikasi), penggabungan (dalam proses komposisi), pemendekan (dalam proses akronimisisasi), dan pengubahan status (dalam proses konversi). Proses ini mencoba menyusun dari komponenkomponen kecil menjadi sebuah bentuk yang lebih besar yang bebentuk kata kompleks atau kata berpolimorfemis (Chaer, 2008:25). Ia menambahkan proses morfologi meliputi (1) bentuk dasar, (2) alat pembentuk (afiksasi, reduplikasi, komposisi, akronimisasi, dan konversi, (3) makna gramatikal, dan (4) hasil proses pembentukan.

Ramlan (2001:51) berpendapat bahwa proses morfologis adalah pembentukan kata-kata dari satuan lain yang berupa bentuk dasarnya. Dalam bahasa Indonesia, terdapat tiga proses morfologis, yaitu (1) poses pembubuhan afiks, (2) proses pengulangan, dan (3) proses pemajemukan (Ramlan, 2001:52).

\section{Afiksasi}

Ramlan (2001:54) berpendapat bahwa afiksasi adalah pembubuhan afiks pada suatu satuan, baik berupa bentuk tunggal maupun bentuk kompleks untuk membentuk kata. Menurut Chaer (2012:8), afiksasi adalah pembubuhan afiks pada bentuk dasar, baik dalam membentuk verba turunan, nomina turunan, maupun kategori turunan lainnya. Sejalan dengan Chaer, Putrayasa (2010:5) mengungkapkan bahwa afiksasi adalah proses pembentukan kata dengan membubuhkan imbuhan pada bentuk dasar, baik bentuk dasar tunggal maupun kompleks.

\section{Pengertian Afiks}

Afiks adalah satuan gramatik terikat yang terdapat dalam suatu kata merupakan unsur yang bukan kata dan bukan pokok kata yang melekat pada 
satuan-satuan lain untuk membentuk kata atau pokok kata baru.

\section{Jenis-Jenis Afiks}

Dalam istilah linguistik, ada bermacam-macam afiks dalam proses pembentukan kata. Menurut Rohmadi dkk (2009:46-49), afiks terdiri atas (1) prefiks, (2) sufiks, (3) infiks, (4) konfiks. Sementara itu, Putrayasa (2010:7-9) berpendapat bahwa jenis-jenis afiks tersebut sebagai berikut.

(1) Prefiks (awalan), yakni afiks yang diletakkan di depan bentuk dasar.

Contoh: meN-, ber-, ter-, pe-, per-, se-

(2) Infiks (sisispan), yaitu afiks yang diletakkan di dalam bentuk dasar.

Contoh: -el-, -er-, -em-, dan -in-

(3) Sufiks (akhiran), yakni afiks yang diletakkan di belakang bentuk dasar.

Contoh: $-a n,-k a n,-i$

(4) Simulfiks, yaitu afiks yang dimanifestasikan dengan cirri-ciri segmental yang dileburkan pada bentuk dasar. Simulfiks dimanifestasikan dengan nasalisasi dari fonem pertama suatu bentuk dasar dan berfungsi membentuk verba atau memverbakan nomina, ajektiva, atau kelas kata lain.

Contoh: dalam bahasa Indonesia nonstandar, yakni kopi menjadi ngopi, soto menjadi nyoto, sabit menjadi nyabit.

(5) Konfiks, yakni afiks yang terdiri atas dua unsur, yaitu di depan dan di belakang bentuk dasar.

Contoh: ke-an, peN-an, per-an, dan ber-an

(6) Imbuhan gabung (kombinasi afiks), yaitu kombinasi dari dua afiks atau lebih yang bergabung dengan bentuk dasar.

Contoh: meN-kan, meN-i, memperkan, memper-i, ber-kan, ter-kan, perkan, peN-an, dan se-nya.
(7) Suprafiks atau superfiks adalah afiks yang dimanifestasikan dengan ciriciri suprasegmental atau afiks yang berhubungan dengan morfem suprasegmental. Afiks tersebut tidak terdapat dalam bahasa Indonesia.

(8) Interfiks, yakni jenis afiks yang muncul di antara dua unsur.

Contoh: interfiks $-n$ - dan $-o$ - pada gabungan Indonesia dan logi menjadi Indonesianlogi.

(9) Transfiks, yaitu jenis infiks yang menyebabkan bentuk dasar menjadi terbagi. Bentuk tersebut tidak terdapatdalam bahasa Indonesia.

Kata yang berupa kata dasar ditulis sebagai satu kesatuan. Dalam hal kata turunan, penulisan kata turunan yang harus diperhatikan adalah (1) imbuhan ditulis serangkai dengan kata dasarnya, (2) awalah atau akhiran ditulis serangkai dengan kata langsung mengikuti atau mandahuluinya jika bentuk dasarnya berupa gabungan kata, (3) jika bentuk dasar berupa gabungan kata sekaligus mendapatkan awalan dan akhiran, katakata itu ditulis serangkai, (4) jika salah satu unsur gabungan kata hanya dipakai dalam kombinasi, gabungan kata itu ditulis serangkai (Sugihastuti, 2007:37).

\section{Pembubuhan Afiks \\ Prefiks $m e N$ -}

Prefiks meN- mengalami perubahan bentuk sesuai dengan kondisi morfem yang mengikutinya dalam pembentukan kata. N (kapital) pada prefiks meN- tidak bersifat bebas, tetapi akan mengalami perubahan bentuk sesuai dengan inisial morfem yang mengikutinya. Prefiks meN- dapat berubah menjadi me-, mem-, men-, meny, meng-, menge-. Bentuk perubahan prefiks $m e N$ - tersebut disebut alomorf prefiks $m e N-$. 


\section{Prefiks ber-}

Prefiks ber- dapat mengalami perubahan bentuk. Ada tiga bentuk yang terjadi jika prefiks ber- dilekatkan pada bentuk dasar. Bentuk-bentuk tersebut adalah be-, ber-, dan bel-.

\section{Konfiks}

Konfiks adalah afiks yang terdiri atas dua bagian; satu bagian terletak pada awal bentuk dasar dan satu bagian lagi pada akhir bentuk dasar (Chaer, 2012:24). Adapun contoh konfiks adalah me-kan, me-i, ke-an, peN-an, per-an, beran, ter-kan, di-i, di-kan.

\section{METODE PENELITIAN}

Penelitian ini bertujuan mendeskripsikan penguasaan proses morfologis pada makalah mahasiswa Malaysia angkatan 2014 Fakultas Syariah UIN Sunan Ampel Surabaya. Berdasarkan tujuan tersebut, penelitian ini merupakan penelitian kualitatif, yakni penelitian yang tidak mengadakan perhitungan atau angka (Moleong, 2001:2).

Sumber data penelitian ini adalah makalah mahasiswa Malaysia angkatan 2014 Fakultas Syariah UIN Sunan Ampel Surabaya. Data penelitian ini adalah katakata dalam makalah mahasiswa Malaysia angkatan 2014 Fakultas Syariah UIN Sunan Ampel Surabaya. Seperti yang telah diungkapkan di atas, jumlah data tersebut ditentukan dengan harapan dapat menganalisis secara mendalam.

Pengumpulan data dalam penelitian ini dilakukan melalui metode dokumentasi. Metode ini dilakukan dengan cara mendokumentasikan lima makalah. Prosedur pengumpulan data dalam penelitian ini adalah (1) pengumpulan makalah, (2) pemfotokopian makalah, (3) pembacaan makalah, (4) penandaan dengan stabilo,
(5) pengklasifikasian, (6) pengodean, (7) pembuatan kartu.

Penganalisisan data dalam penelitian ini menggunakan metode deskriptif. Artinya, peneliti hanya mendeskripsikan proses morfologis. Adapun tahap-tahap yang digunakan dalam penganalisisan data adalah (1) pengumpulan data, (2) pengklasifikasian data, dan (3) penginterpretasian. Pemeriksaan keabsahan penelitian ini menggunakan teknik ketekunan pengamatan, triangulasi, dan pengecekan teman sejawat.

\section{HASIL DAN PEMBAHASAN Afiksasi}

Ramlan (2001:54) berpendapat bahwa afiksasi adalah pembubuhan afiks pada suatu satuan, baik berupa bentuk tunggal maupun bentuk kompleks untuk membentuk kata. Menurut Chaer (2012:8), afiksasi adalah pembubuhan afiks pada bentuk dasar, baik dalam membentuk verba turunan, nomina turunan, maupun kategori turunan lainnya. Sejalan dengan Chaer, Putrayasa (2010:5) mengungkapkan bahwa afiksasi adalah proses pembentukan kata dengan membubuhkan imbuhan pada bentuk dasar, baik bentuk dasar tunggal maupun kompleks.

\section{Prefiks}

Prefiks adalah afiks yang terletak di depan bentuk dasar. Adapun afiks yang ditemukan sebagai berikut.

Data:

(10) ... penulis dapat menyelesaikan tugas ini ....

(11) Penulis telah menganalisa masalah pada ....

(12) ...memberikan rahmat dan petunjuk ... sebagai penulis sehingga makalah ini ....

(13) ... kemampuan yang penulis miliki.

(14) $\ldots$ oleh pelajar Jurusan ....

(15) ... selaku dosen pembimbing mata kuliah ... senantiasa membimbing ....

(16) ... para pembaca saya menerima dengan lapang dada.

(17) ... anggota masyarakat pemakai suatu 
bahasa untuk menuliskan bahasanya.

(18) Pemakalah menyadari bahwa makalah ini masih jauh dari sempurna.

(19) ...memberikan rahmat dan petunjuk ... sebagai penulis sehingga makalah ini ....

(20) ... tugas dan petunjuk kepada kami, ....

(21) ... sebagai pengguna bahasa Indonesia ....

(22) Semoga isi dari tugas saya bermanfaat bagi yang ....

(23) Berusaha memperbetulkan kesalahan tanda baca tersebut ....

(24) Sarana belajar dan giat berlatih merupakan ....

(25) Bahasa Melayu Kuno ini kemudian berkembang pada berbagai tempat di Indonesia terutama pada masa ....

(26) Kalau kita melihat perkembangan bahasa Indonesia ...

(27) Setelah membuat kajian ilmiah ini terdapat ...

(28) Kalimat-kalimat akan lebih tersusun rapi.

(29) Bahasa Melayu Kuno ini kemudian berkembang pada berbagai tempat di Indonesia terutama pada masa ....

(30) Selepas menganalisa kesalahan ....

(31) Setiap tanda baca memiliki fungsinya tersendiri.

(32) Berdasarkan hasil penelitian yang telah dikaji ....

(33) ... pada makalah yang dipilih.

Data (1-12) mengandung prefiks pe-, yakni pada kata penulis, pelajar, pembimbing, pembaca, pemakai, pemakalah, petunjuk, pengguna. Pada data (1-4), kata penulis terbentuk dari awalan pe-+kata dasar tulis mengalami morfofonemik menjadi pen- menjadi penulis yang berarti 'orang yang melakukan pekerjaan menulis'. Data (5) mengandung kata pelajar. Kata pelajar terbentuk dari awalan pe-+kata dasar ajar mengalami morfofonemik menjadi pelmenjadi pelajar yang berarti 'orang yang sedang belajar'. Pada data (6-8), kata pembimbing, pembaca, dan pemakai terbentuk dari awalan pe-+kata dasar bimbing, baca, dan pakai mengalami morfofonemik menjadi pem- menjadi pembimbing, pembaca, dan pemakai. Kata pembimbing, pembaca, dan pemakai berarti 'orang yang me-'. Data (9-11) mengandung kata pemakalah dan petunjuk. Kata pemakalah dan petunjuk terbentuk dari awalan pe-+kata dasar makalah dan tunjuk. Kata pemakalah berarti 'orang yang membuat', sedangkan petunjuk berarti 'orang yang memberikan'. Pada data (12), terdapat kata pengguna terbentuk dari awalan pe+kata dasar guna mengalami morfofonemik menjadi peng- menjadi pengguna yang berarti 'orang yang menggunakan'.

Pada data (13-16), terdapat kata bermanfaat, berusaha, berlatih, dan berkembang. Kata bermanfaat berusaha, berlatih, dan berkembang terbentuk dari awalan ber-+kata dasar manfaat, usaha, latih, dan kembang. Kata bermanfaat berarti 'memiliki', sedangkan kata berusaha, berlatih, dan berkembang memunyai arti 'melakukan pekerjaan'. Data (17-18) mengandung kata melihat dan membuat. Kata melihat dan membuat terbentuk dari awalan $m e(N)-+$ kata dasar lihat dan buat. Pada kata melihat, terbentuk dari awalan me-+kata dasar lihat dan kata membuat terbentuk dari awalan me+kata dasar buat mengalami morfofonemik menjadi mem- menjadi membuat. Kedua kata tersebut berarti 'melakukan pekerjaan'.

Data (19-20) mengandung kata tersusun dan terutama. Kata tersusun terbentuk dari awalan ter-+ kata dasar susun yang berarti 'telah disusun'. Pada kata terutama, terbentuk dari awalan ter-+kata dasar utama yang berarti 'paling utama'. Pada data (21-22), terdapat kata setiap dan selepas. Kata selepas terbentuk dari awalan se-+kata dasar lepas yang berarti 'setelah lepas dari'. Kata setiap terbentuk dari awalan se-+kata dasar tiap. Dalam konteks kalimat tersebut, setiap memiliki makna 'satu tiap tanda baca'. Data (2324) mengandung kata dikaji dan dipilih. Kata dikaji dan dipilih terbentuk dari awalan di-+kata dasar kaji dan pilih yang bermakna 'telah melakukan pekerjaan'. 


\section{Sufiks}

Sufiks adalah afiks yang diletakkan di belakang bentuk dasar. Data yang mengandung sufiks seperti di bawah ini.

(34) $\ldots$ atas limpahan ramat dan karunia-Nya ... Pelajar Jurusan Kaunseling 2014.

(35) ... selalu memberikan dukungan moral.

(36) ... dalam kalimat berdasarkan tujuan dan kecocokannya.

(37) $\ldots$ organisasi suatu tulisan, dan ....

(38) ... dilihat pada bahasan di atas ....

(39) Setiap tanda baca memiliki fungsinya yang tersendiri.

(40) Pada hakikatnya, ejaan itu ....

(41) Puji syukur kami panjatkan kebesaran Allah ....

(42) Disamping itu, izinkan penulis untuk ....

(43) ... kemampuan yang penulis miliki.

Pada data (1-5), terdapat sufiks -an, yakni kata limpahan, dukungan, tujuan, tulisan, bahasan, dan ucapan. Kelima kata tersebut terbentuk dari sufiks -an+kata dasar limpah, dukung, tuju, tulis, bahas, dan ucap. Arti kelima kata tersebut adalah 'hasil'.

Data (6-7) mengandung kata fungsinya dan hakikatnya. Kedua kata tersebut terbentuk dari sufiks -nya+kata dasar fungsi dan hakikat. Nomina bersufiks - nya tersebut memiliki fungsi 'memberi penekanan atau penegasan'. Pada data (8-9), terdapat kata panjatkan dan izinkan. Kedua kata tersebut mendapatkan sufiks -an. Kata panjatkan terbentuk dari sufiks -kan+kata dasar panjat yang berarti 'melakukan pekerjaan' dan kata izinkan terbentuk dari sufiks -an+kata dasar izin yang berarti 'melakukan pekerjaan'. Data (10) mengandung kata miliki. Kata miliki terbentuk dari sufiks - $i+$ kata dasar milik yang berarti 'merasa sesuatu pada'.

\section{Konfiks}

Konfiks adalah afiks yang terdiri atas dua unsur, yaitu di depan dan di belakang bentuk dasar. Data yang mengandung konfiks seperti di bawah ini.

(44) ... sehingga penulis dapat menyelesaikan ...
Penggunaan Ejaan ....

(45) ... kami dapat menyelesaikan ....

(46) ... kami dapat menyelesaikan ....

(47) ... dapat menyelesaikan tugas akhir semester

(48) ... dapat menyelesaikan tugas ini.

(49) ... menyampaikan ucapan terima kasih ....

(50) Penulis menyampaikan terima kasih ... mendoakan dalam segala hal walaupun dalam jarak yang jauh.

(51) Pemakalah menyadari bahwa makalah ini masih jauh dari sempurna.

(52) ... menulis dan mengakhiri kalimat tersebut ....

(53) Berdasarkan analisis data ....

(54) Tugas ini berisikan ....

(55) ... dapat terselesaikan pada waktu yang telah ditetapkan.

(56) Tanda baca merupakan tanda-tanda yang digunakan di dalam bahasa tulis ....

(57) ... tanpa disadari kalaupun sebelumnya ....

(58) ... banyak dipengaruhi bahasa Sansekerta ....

(59) Kalau kita melihat perkembangan bahasa Indonesia ....

(60) Penulisan karya ilmiah yang benar ....

(61) Kesalahan tanda baca pada makalah ....

(62) Puji syukur kami panjatkan kebesaran Allah

(63) ... tidak mengulangi ....

(64) ... dapat terselesaikan pada waktu yang telah ditetapkan.

Data (1-5) mengandung konfiks me-kan. Kata menyelesaikan berasal dari konfiks me-kan+kata dasar selesai yang bermakna 'melakukan perbuatan'. Pada data (6-7), terdapat kata menyampaikan dan mendoakan. Kata menyampaikan berasal dari konfiks mekan+kata dasar sampai dan kata mendoakan berasal dari konfiks mekan+kata dasar doa yang keduanya bermakna melakukan perbuatan.

Pada kata (8-9), terdapat kata menyadari dan mengakhiri. Kata menyadari terbentuk dari konfiks $m e-i+$ kata dasar sadar mengalami proses morfofonemik menjadi meny- $i$ karena bentuk dasarnya dimulai dengan konsonan bersuara /s/ sehingga menjadi menyadari yang berarti 'merasa (sadar)'. Data (9) mengandung kata mengakhiri yang terbentuk dari konfiks me-i+kata dasar akhir dan 
mengalami proses morfofonemik penambahan fonem nasal /ng/ karena bentuk dasarnya dimulai dengan konsonan /a/ sehingga menjadi mengakhiri yang bermakna 'membuat jadi yang disebut kata dasar pada objeknya'.

Data (10-11) mengandung kata berdasarkan dan berisikan. Kedua kata tersebut mendapatkan konfiks ber-kan. Kata berdasarkan dan berisikan terbentuk dari konfiks ber-kan+kata dasar dasar yang berarti 'memakai dasar', sedangkan kata berisikan terbentuk dari konfiks ber-kan+kata dasar isi yang berarti 'memunyai isi'.

Pada data (12-13), terdapat kata ditetapkan dan digunakan. Kedua kata tersebut terbentuk dari konfiks $d i$ kan+kata dasar tetap dan guna yang bermakna 'melakukan pekerjaan'. Data (14-15) mengandung kata disadari dan dipengaruhi. Kedua kata tersebut terbentuk dari konfiks di-i+kata dasar sadar dan pengaruh yang bermakna 'menyatakan hal seperti tersebut pada kata dasar'. Pada data (16-17), terdapat kata perkembangan dan penulisan. Kata perkembangan terbentuk dari konfiks per-an+kata dasar kembang dan kata penulisan terbentuk dari konfiks pean+kata dasar tulis mengalami proses morfofonemik, yaitu bentuk dasar yang diawali konsonan /t/ diluluhkan dengan nasal $/ \mathrm{n} /$. Kedua kata tersebut bermakna 'proses'.

Data (18-19) mengandung kata kesalahan dan kebesaran. Kedua kata tersebut terbentuk dari ke-an+kata dasar salah dan besar yang berarti 'hal'. Pada data (20), terdapat kata mengulangi. Kata mengulangi terbentuk dari konfiks me$i+$ kata dasar ulang yang bermakna 'melakukan pekerjaan berulang-ulang'. Data (21) mengandung kata terselesaikan. Kata terselesaikan terbentuk dari konfiks ter-kan+kata dasar selesai yang bermakna 'menyatakan sesuatu keadaan yang dapat di-'.

\section{PENUTUP \\ Simpulan}

Penguasaan afiksasi pada makalah mahasiswa Malaysia UIN Sunan Ampel Surabaya meliputi (a) prefiks, yaitu $p e(N)-$,ber-, se-, me $(N)$-, ter- dan de-. (b) Sufiks, yaitu -an, -kan, -nya, dan -i. (c) konfiks, yaitu $m e(N)-k a n, k e-a n$, $m e(N)-i$, ber-kan, di-kan, di-i, pe(N)-an, di-kan, di-nya, dan se-nya.

\section{Saran}

Beberapa saran yang sehubungan dengan hasil penelitian adalah sebagai berikut.

(1) Sebaiknya, mahasiswa asing mengikuti pelatihan, penataran, workshop untuk meningkatkan kemampuan menulis;

(2) Mahasiswa asing diharapkan banyak membaca buku-buku terbitan baru agar wawasan tentang menulis bertambah;

(3) Mahasiswa asing diharapkan sering menulis agar kemampuan menulisnya semakin meningkat.

\section{DAFTAR PUSTAKA}

Chaer, Abdul. 2008. Morfologi Bahasa Indonesia (Pendekatan Proses). Jakarta: Rineka Cipta.

\section{Seputar Tata} Bahasa Baku Bahasa Indonesia. Jakarta: Rineka Cipta. 2013. Pembinaan Bahasa Indonesia. Jakarta: Rineka Cipta.

Moleong, Lexy J., (2001), Metodologi Penelitian Kualitatif, bandung : PT Remaja Rosdakarya. 
Muslich, Masnur. 2012. Bahasa Indonesia pada Era Globalisasi. Jakarta: Rineka Cipta.

Putrayasa, Ida Bagus. 2010. Kajian Morfologi (Bentuk Derivasional dan Infleksional). Bandung: Refika Aditama.
Ramlan. 2001. Morfologi Suatu Tinjauan Deskriptif. Yogyakarta: Karyono.

Sugihastuti. 2007. Bahasa Laporan Penelitian. Yogyakarta: Pustaka Pelajar. 